\title{
Ten Successful Years: A Longitudinal Case Study of Autonomy, Control and Learning'
}

\section{Heidi Enehaug ${ }^{2}$}

PHD-student, Oslo and Akershus University College of Applied Sciences, Norway/Roskilde University, Denmark

\begin{abstract}
The article examines three concepts closely related to the Nordic sociotechnical tradition: responsible autonomy, learning, and control. The longitudinal case study analyses the implementation of a 6-hour workday and the development of responsible autonomy, employee control, and productive organizational learning in a Nonwegian factory from 2001 to 2012. The development process was successful, with productivity increasing by $20 \%$ within I year. We found that productivity improvements and positive work environment changes were made possible by developing responsible autonomy through an employee-driven innovation process that led to a focus on quality and productivity throughout the organization. We also found that the development of responsible autonomy prevents defensive routines from disrupting the learning and development processes in the organization. We conclude that successful organizational development depends upon building responsibility through organizational learning.
\end{abstract}

\section{KEYWORDS}

Employee control / change / defensive routines / organizational learning / responsible autonomy / restructuring

\section{Introduction}

rganizational change and workplace restructuring is often associated with failure (Jacobs et al., 2013), with adverse effects on the psychosocial work environment, employee health, and overall sickness absence rates (see, e.g., Bambra et al., 2007; Egan et al., 2007, 2014; Enehaug \& Thune, 2007; Enehaug, 2014).(Kivimäki et al., 2000). This may be caused by increased job strain or stress (Kivimäki et al., 2003; Korunka et al., 2003) or job insecurity (DeWitte, 1999). An underestimation of the significance of the quality of the organizational change process (Balzer et al., 2011; DahlJørgensen \& Saksvik, 2005; Nytrø et al., 2000; Saksvik et al., 2002) or the lack of active employee involvement in the process (Holter et al., 1998) may also cause problems. Organizational change is not delimited to singular processes with a fixed starting point and a defined end, but can be seen as 'situated and grounded in continuing updates of work processes and social processes' (Weick \& Quinn, 1999, p. 375, referring to Brown

\footnotetext{
${ }^{1}$ You can find this text and its doi at https://tidsskrift.dk/njwls/index.

${ }^{2}$ Heidi Enehaug, Oslo and Akershus University College of Applied Sciences, Box 4, St. Olavs plass, 0130 Oslo, Norway. E-mail: heidi.enehaug@afi.hioa.no.
} 
\& Duguid, 1991, and Tsoukas, 1996). Research on adverse effects of restructuring is not always suited to explain successful change. An alternative approach is to look at organizational learning capabilities as a prerequisite for the identification of and implementation of changes in ideas, practices, and routines (Argyris \& Schön, 1996).

This perspective resonates with the sociotechnical perspective on organizations, which in Norway dates back to the late 1960s. The Industrial Democracy Projects (IDPs) sought to develop work place democracy and increase individual involvement in the work organization, emphasized the significance of both codetermination and participation, and considered it fundamental to create self-supporting organizational development based on learning and the expression of human resources (Gustavsen et al., 2010; Herbst, 1971; Thorsrud \& Emery, 1970). The development of Industrial Democracy, first in Sweden and later in Norway, also gave direction to the development of the Nordic/Norwegian model-a model characterized by trustful relations between workers and employers, an active use of the society's horizontal relations to minimize conflicts, and the promotion of productivity and innovation (Falkum, 2015; Gardell \& Svensson 1981; Gustavsen, 2007, 2011; Hasle \& Sørensen 2013; Hvid, 2013; Kasvio et al., 2012; Sørensen et.al 2012).

In the decades following the 1970 s, Norway was affected by internalization, globalization, digitalization, and European integration (Dølvik, 2007), and by various organizational swings (Røvik, 1998). It is debatable whether these changes have affected the alignment of the Norwegian model. Dølvik (2007) contends that the Norwegian welfare state and work institutions are characterized by continuity and adaptation. Heiret (2012) emphasizes that flexibility demands are challenging existing regulations in today's version of the model, and Falkum et al. (2016) claim that the implementation of new forms of organization and management, based on standardization and control, loyalty, and commitment, constitutes a challenge. Nevertheless, the existence of a Norwegian cooperative model based on participation, codetermination, and trust seems unquestioned thus far.

In this article, we analyze the 10-year ongoing restructuring process in one organization by focusing on the processual development of responsible autonomy and employee control. We further view the organizational change process through the case organization's capacity for organizational learning and its ability to overcome inherent defensive routines that may jeopardize productive learning (Argyris, 1990). We argue that this restructuring process is characterized by values and practices in accordance with the IDP and the Norwegian work life model. We see this as a key factor to understanding this organization's successful transformation.

\section{Learning, Work Environment, and Productivity}

Together, four partially overlapping concepts guide the analysis of the change process: the core sociotechnical concept responsible autonomy, the control concept of Karasek and Theorell, and Argyris and Schön's concepts of productive learning and defensive routines. Combining the control and learning dimension expands the original autonomy concept and reunites contributions from the organizational learning and the work environment research with the sociotechnical perspective from which they originate (cf. Enehaug, 2014).

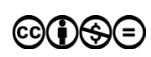




\section{Responsible Autonomy}

The term responsible autonomy (Trist \& Bamforth, 1951; Trist et al., 1963) constitutes a mix between individual and group responsibility. A key point is that autonomy is set in play within a community of colleagues-it is not an individual asset. All individuals are interdependent on each other, their team, and the entire cycle of operations. Individuals have a shared responsibility for meeting the demands of work and contributing to the development of work on both an individual and an intergroup level. Both responsibility and autonomy are fluctuating variables constantly negotiated through dialogue and the practicing of work tasks.

\section{The Employee Control Concept in the D/C Model}

Karasek and Theorell's (1979, 1990) Demand/Control model claims that control and autonomy in one's own work is of great importance for the psychosocial environment and for the learning abilities of individuals and organizations. The control dimension of this model consists of a scale labeled 'decision latitude', described by two subscales: 1) skill discretion, concerning task variation, uniformity, job-related creativity, the competence demands of the job, and the possibilities to learn new things and develop skills; and 2) task authority, concerning the possibilities for making job-related decisions, determining how to perform the work, and influencing the way the work is organized.

We consider the control concept both as an individualistic approach to organization and, in accordance with Hvid (2009), a perspective of the psychosocial work environment, also known as the collective dimension. With the two subscales taken into account, the control concept significantly extends the concept of responsible autonomy.

\section{Defensive routines and productive organizational learning}

Argyris and Schön (1996) understood organizational learning as what happens when individuals make inquiries on behalf of the organization by asking questions about problematic situations and by suggesting ways to solve them. A central element in productive organizational learning is the identification of defensive routines, which inhibit the organization from changing its practice, learning in a productive manner, and conducting a 'high-quality inquiry' on behalf of the organization. Defensive routines form patterns of 'skilled incompetence' that are activated when managers or employees find themselves in embarrassing or threatening situations and act to help them 'save face'. The following rules define defensive routines:

1) Craft messages that contain inconsistencies; 2) Act as if the messages are not inconsistent; 3) Make the ambiguity and inconsistency in the message undiscussable; 4) Make the undiscussability of the undiscussable also undiscussable. (Argyris \& Schön, 1996, p. 100)

There are three types of productive organizational learning: 1) organizational inquiry that improves the way tasks are solved; 2) inquiry in which the organization explores 
and restructures values and criteria for better performance; and 3) inquiry that betters the organizational learning of both types 1 and 2 .

\section{Research questions}

This article examines the long-term change process in one organization, seeking thereby to answer two key questions:

1. Can the development of responsible autonomy, employee control, and productive organizational learning explain the results of the change process in this organization?

2. Are the concepts productive organizational learning, responsible autonomy, and employee control interrelated, and if so, what are the implications?

\section{Data and Methods}

\section{Study setting}

Empirical data (Tab. 1) were collected from a singular case, which has undergone major changes with regard to production, cooperation, management, work hours, and shift schedules. The industrial plant has about 180 employees (62\% men, 38\% women), divided into the administrative department, the workshop/technical department, the storage department, and the packaging department. The work consists of packaging cheese (assembly line), making the cheese ready for distribution, maintaining machinery, management and administration, and an in-house canteen.

In 2006, the organization decided to implement a 6-hour workday project (SHWDP). The overall goal was to increase the employees' quality of living. At the same time, a prerequisite for the project was a) that productivity did not fall, b) that the sickness absence did not increase, and c) that the employees would take responsibility for the development of the new organization. Ultimately, the development process proved successful: the productivity increased by $20 \%$ after approximately 1 year, there was no rise in sickness absence, and job satisfaction was high. In 2013, the overall productivity had increased by $50 \%$.

\section{Study design}

This qualitative research project is exploratory and focuses on the local descriptions and perceptions of the change process. We consider this a critical case because of its longitudinal character and argue that the use of analytical generalization takes place by using theoretical concepts in the data analysis and in the effort to advance these concepts (Yin, 2014, pp. 41-53).

The data material (Tab. 1) was collected at three different points in time and consists of a document study, 53 in-depth interviews, six focus group interviews, one organization-wide survey, and observation in two problem-solving groups. 'Guided 


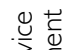

बi

วิ)

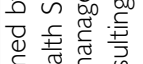

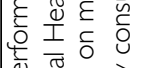

จิ

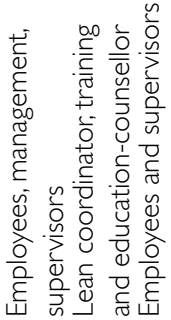

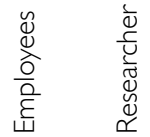
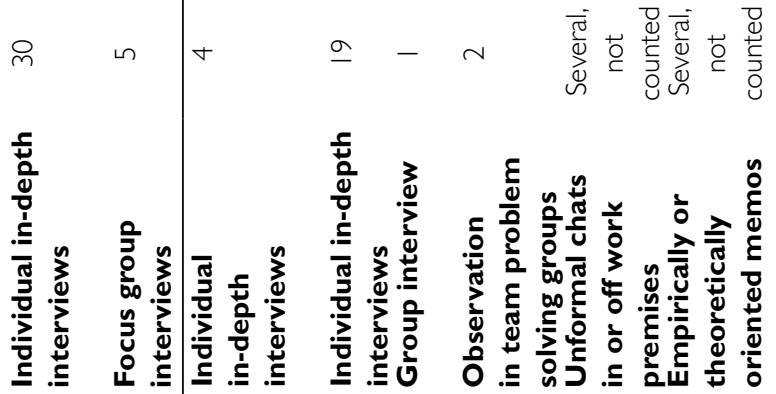

ठे
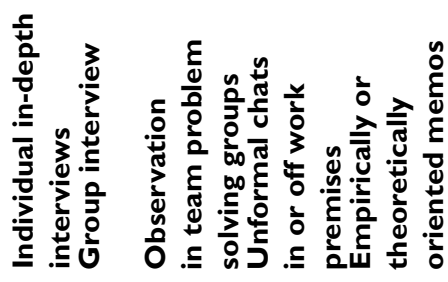

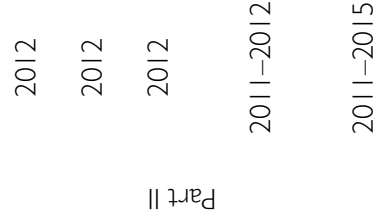


tours' of the production facilities took place in both of the main phases of the data collection to better understand the work flow and the physical work environment. Uncounted informal chats during field visits provided relevant input in field memos, or in the interviews. Theoretical, empirical, or mixed memos are considered a part of the data material.

\section{Interviews}

The interviews lasted for approximately 1,5 hours and were either transcribed based on handwritten notes or recorded and transcribed. In both of the main data collection periods, the organization selected interviewees following certain criteria; seniority, position, and departmental affiliation. The focus group interviews lasted for about 2 hours and were recorded and transcribed. There was an uneven distribution of gender in the organization in total (62\% men, $38 \%$ women) and also among the interviewees $(20 \%$ women). One-third of the focus groups participants were women. Gender was not used as an analytical background variable.

\section{Data Analysis}

The change processes addressed in this study dates back to 2001. Several interviews are retrospective - the informants reflected upon issues of the past. These interviews and the document analysis provide an approach to the perceptions of the development of the organization. The various parts of the material are weighed differently in the analysis. The survey material will only briefly be mentioned and mainly used as background information. The data material from 2009 was part of a research and evaluation project performed by two fellow researchers and myself. The complete 2009 qualitative data material was reanalyzed and recoded for this article.

The interviews and documents were analyzed using margin notes, simple coding and messy situational maps to gain an overview of the content (Clarke, 2005; Creswell, 2013; Patton, 2002). NVIVO 10 was then used to develop broader categories and themes. An analysis of the total material over time, based on selected themes and categories and groups of informants was carried out. The main analytical categories were: significant organizational choices, work environment issues, organizational learning, and organizational defenses.

\section{Limitations}

Throughout the period of restructuring, the plant was subjected to extensive attention due to several evaluations and press reports. The research presented here has contributed to the attention. This raises two analytical implications. First, has the potential closeness between researchers and the organization jeopardized the analytical distance? Most probably not, as the data collection took place over a long period, but field visits were limited in number. Second, has the repeated attention affected the organization's positive assessment of the development process and the results (cf. the Hawthorne 
effect)? Possibly. But it can be argued that the employee-driven process per se resulted in a raised awareness of positive aspects of work, responsible autonomy, and employee control.

\section{Ten Successful Years - How did They do it?}

We present the results as a discussion of three partially overlapping phases (Tab. 2). Each phase identifies specific events, perceptions of selected work environment issues, types of organizational learning, and organizational defenses.

Table 2 Organizational choices, work environment issues, organizational learning, and organizational defenses, by phase in organizational development

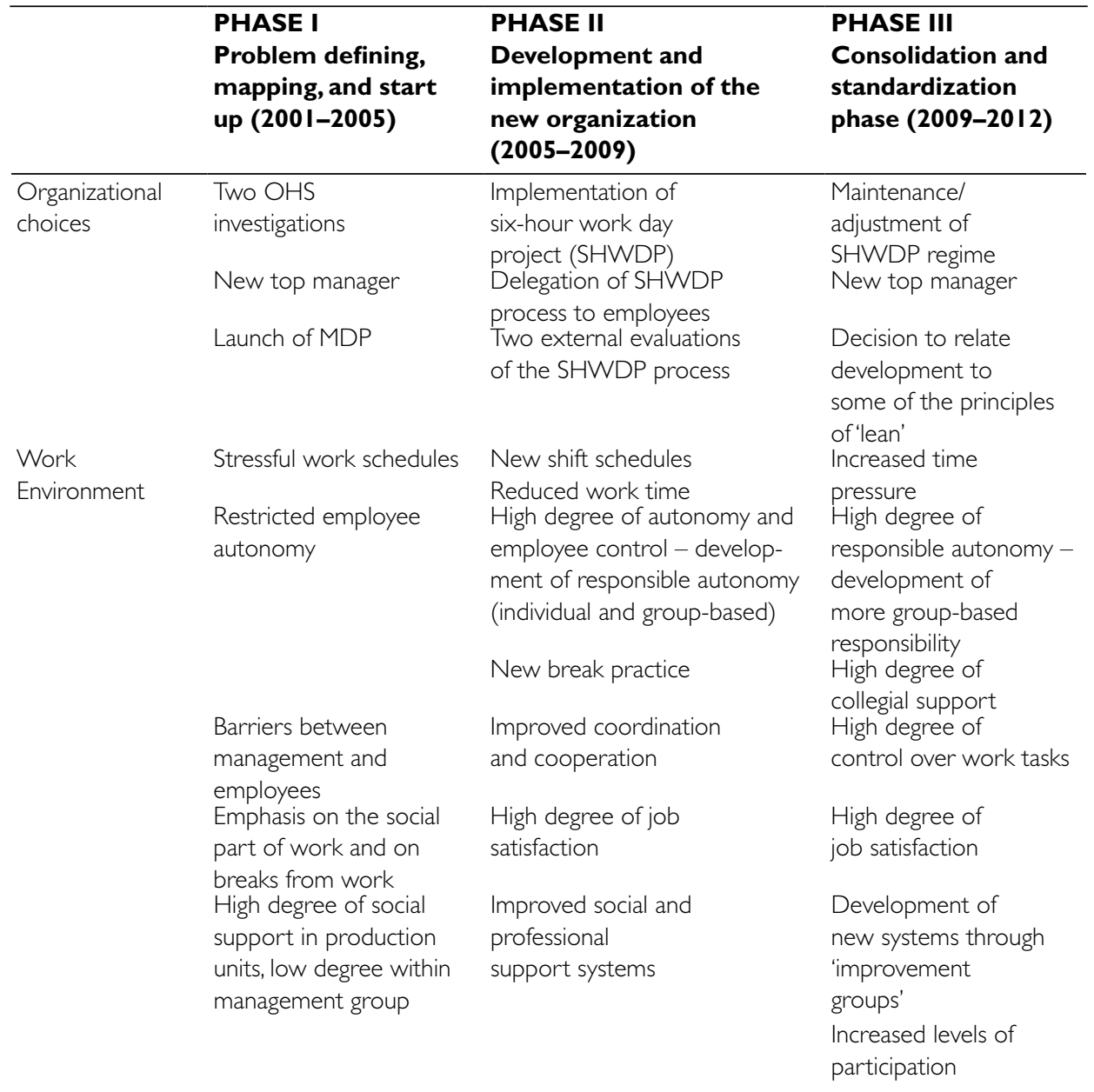


Table 2: (Continued)

\begin{tabular}{|c|c|c|c|}
\hline & $\begin{array}{l}\text { PHASE I } \\
\text { Problem defining, } \\
\text { mapping, and start } \\
\text { up (200I-2005) }\end{array}$ & $\begin{array}{l}\text { PHASE II } \\
\text { Development and } \\
\text { implementation of the } \\
\text { new organization } \\
(2005-2009)\end{array}$ & $\begin{array}{l}\text { PHASE III } \\
\text { Consolidation and } \\
\text { standardization } \\
\text { phase }(2009-20 \text { I } 2)\end{array}$ \\
\hline $\begin{array}{l}\text { Organizational } \\
\text { learning }\end{array}$ & $\begin{array}{l}\text { Development of } \\
\text { new competencies within } \\
\text { leader group and through } \\
\text { development of } \\
\text { trust } \\
\text { Improved } \\
\text { coordination } \\
\text { between members } \\
\text { of leader group } \\
\text { (late in phase } \\
\text { period) }\end{array}$ & $\begin{array}{l}\text { Development of new } \\
\text { work practices } \\
\text { and routines } \\
\text { Transition from a } \\
\text { community of } \\
\text { colleagues toward } \\
\text { practicing work teams } \\
\text { From development of } \\
\text { instrumental } \\
\text { learning toward high } \\
\text { degree of productive } \\
\text { organizational learning }\end{array}$ & $\begin{array}{l}\text { High degree of } \\
\text { productive } \\
\text { organizational } \\
\text { learning, types I and } 2 \\
\text { Further development of } \\
\text { management } \\
\text { at all levels } \\
\text { Employees develop } \\
\text { new skills }\end{array}$ \\
\hline \multirow[t]{4}{*}{$\begin{array}{l}\text { Organizational } \\
\text { defenses }\end{array}$} & Fear of reprisal & $\begin{array}{l}\text { Lack of ability to discuss } \\
\text { problems in } \\
\text { connection with } \\
\text { 'no-participation } \\
\text { strategies'/the dodgers }\end{array}$ & $\begin{array}{l}\text { Time rationality } \\
\text { vs. responsible } \\
\text { autonomy }\end{array}$ \\
\hline & Skilled incompetence & & $\begin{array}{l}\text { Partial cover-up } \\
\text { strategies }\end{array}$ \\
\hline & $\begin{array}{l}\text { Low degree of trust } \\
\text { within the leader group, } \\
\text { making it difficult to } \\
\text { discuss problematic issues; } \\
\text { cover-up strategies }\end{array}$ & $\begin{array}{l}\text { Employee resistance and } \\
\text { cover-up strategies }\end{array}$ & $\begin{array}{l}\text { The six-hour work day } \\
\text { as control } \\
\text { mechanism }\end{array}$ \\
\hline & $\begin{array}{l}\text { Mid-level managers } \\
\text { double-bind }\end{array}$ & & \\
\hline
\end{tabular}

\section{Phase I: Problem defining and mapping (200I-2005)}

In the first phase of the change process, three important organizational choices were made. First, the OHS made two separate investigations of the psychosocial work environment. Second, a new top manager started. Third, a management development process (MDP) was launched.

\section{Work environment and management issues - intertwined}

After a resolution in the internal work environment committee, the Occupational Health Service (OHS) investigated the psychosocial work environment of the administrative 
staff (2001). This investigation revealed partially contradictive aspects of the work environment. On the one hand, the administration experienced job engagement, a high degree of autonomy and motivation, and good possibilities for learning and development in the work. On the other hand, the collegial social support system was not satisfactory, and there was little or no professional support. The OHS concluded that the top manager's leadership style had set in motion a high degree of insecurity within the management group. This contributed to the development of a deep-rooted trust deficiency that over the years became an integral part of the organizational identity. A new OHS-investigation 2 years later problematized the fact that the former top manager still had a position within the organization. Several employees were against this second investigation because of 'the strong reaction of the former top manager after the 2001 investigation' (OHS-report 2003). This quote illustrates a period-specific cultural trait in the administrative unit - the fear of reprisal. Even after the inauguration of a new top leader (2002), the impact of the former manager is substantial in this part of the organization. The new manager had different ideas of organizational development and management in general, formed by prior management experiences. According to him, the leader group had poor decision-making skills. One important aspect of the upcoming change in the leadership group was that the main union representative in the organization was included as a regular member. This changed the cooperation between managers and employees and contributed to the development of internal trust in the organization.

The work environment in the other units is less documented. What we have are recollections made by informants (2008 and 2009) where they compare today with 'earlier'. The work environment was perceived as good, the work tasks satisfactory, the pace of work not stressful, and the social support system functional. Further analysis nevertheless revealed dysfunctional traits. Because of the controlling management style at all levels, autonomy was limited and resulted in many disruptions of the work. Whenever something went wrong (e.g., machine errors along the assembly line), the workers immediately stopped working while waiting for technical support, regardless of whether they themselves could solve the problem or not. We see this as an example of 'skilled incompetence'. Another interesting factor is that fixed breaks were carried out at regular time intervals. Meanwhile, the assembly line stopped, something that had consequences for productivity and the social climate. It was a setback in terms of efficiency: managers and employees agreed that this was inexpedient and time-consuming, because 'the worst you can subject an assembly line to is the stop/restart procedure'. Nevertheless, the break practice contributed to both job satisfaction and the development of job-related friendships. But, when break practices later changed, employees found (to their surprise) that their sense of social belonging was improved. The most stressful part of the work in this phase was the shift schedule, which affected the mental and physical state of the employees.

\section{Organizational learning and organizational defenses}

The parallel processes of mapping the work environment and the MDP can be seen as the first steps in the development of organizational learning capabilities. The first round of the MDP was launched through the hiring of a consulting company (2004), which resulted in an organizational analysis and various workshops over a 3-year period. 
The early part of phase I (before the new top manager) also displayed a mid-level managers' double bind. To protect their employees from direct confrontations with the top manager, the managers developed defense mechanisms that included avoiding the problem by withholding information on how bad things were and by not addressing the problematic issues within the leader group. The result was that many employees had a positive image of the top manager. This contributed to a divide between management and employees within the organization.

The tendency to not deal with problems in the performance of daily tasks continued to be problematic for some of the managers throughout this phase there were trust deficiencies among mid-level managers, lower-level managers, and the employees. The managers perceived the employees as difficult to deal with, the employees did not accept the authority of the managers, and the managerial style incited resistance from employees. Even if employees were encouraged to provide opinions on the work organization, their input was not taken into account. There seemed to be an increasing 'escalation of new top-down control mechanisms' initiated to address upcoming problems (Consultancy report 1/2005) instead of focusing on participation bottom-up. This again hindered the development of responsible autonomy.

\section{Phase II: Development and implementation of the new organization (2005-2009)}

Two important choices were made during the second phase of the process. The first of these was to implement the 6-hour work day project (SHWDP) in 2007. The second was to delegate the development to the employees as much as possible. A large number of employees participated in project groups working on ways to reduce the work hours by 1.5 hours per day, and simultaneously keep up with/increase production without increasing sickness absence. Two external evaluations of the SHWDP project were conducted in this phase.

\section{Work environment}

The first external work environment evaluation, conducted after the SHWDP had been running for about 1 year, concluded that the employees preferred the new work schedule to the old, despite increased work demands (time pressure and the possibility of having fixed breaks). Better coordination and cooperation in the organization, work-hour reduction, and the rearranging of shift schedules, functioned as coping mechanisms and made the increased work load unproblematic.

The second external evaluation and a comparative analysis of both evaluations show the development from before the implementation of the SHWDP, plus 1 and 2 years in the running. ${ }^{1}$ It is beyond the scope of this article to present the detailed analysis of these changes, but selected findings are listed below:

- The shift schedule was perceived as less stressful in 2009 than in 2007.

- The percentage of employees who considered they had a very good opportunity

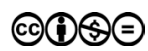


to perform their work according to professional standards was increasing $(36 \%$ in $2007,44 \%$ in 2008 , and $49 \%$ in 2009 ).

- There is an increase in the total percentage of employees who had a good/very good opportunity to influence how they carry out their work tasks (from $60 \%$ to $71 \%$ and then $72 \%$ ) - but the administrative unit and the workshop/technical unit $100 \%$ and $86 \%$, respectively) have substantially higher scores than the employees in the storage unit and the packaging unit $(27 \%$ and $16 \%$, respectively).

- The collegial social support system was improved, with $23 \%$ in 2007 and $38 \%$ in 2009 having very good opportunities for help and support from colleagues.

- Even though six out of ten experienced time pressure as high in 2009 (slightly lower than 2007 and 2008), only a small percentage (6\%) felt exhausted when the work day was over. In addition, fewer experienced exhaustion after one week's work.

The interview study in 2009 supports the above survey findings. The employees describe a situation in which their input and suggestions are taken into account on a daily basis, and where work tasks are soved in a smarter way.

\section{Organizational learning}

In phase II, a considerable amount of work and resources was allocated to changing and improving production practices, organizing work tasks, and strengthening internal cooperation. These efforts were mainly directed toward the development and implementation of the SHWDP. However, several actions were carried out in order to ensure that not only the participants in the SHWDP groups were heard; as a kick-off, the whole plant was shut down for a day and a seminar was held. Several information meetings took place, and the parallel processes of management development and certificate training continued. OHS work was on the agenda, and annual job satisfaction surveys were conducted.

New roles. The MDP continued and contributed to a stronger sense of mastery and a development of trust in the organization, especially within the leadership group. The managers themselves emphasized how the dialogue-oriented conversations, facilitated as part of the MDP, by the end of this phase acted more as an integral part of managing on a day-to-day basis. In this way, there was a change both in the mindset of the managers and in the decision-making practice. The control practice, typical of the former top manager, no longer took place, and the evolution of a flat organizational structure and of new managerial roles had started. As one of the managers explained,

My leader gives me responsibility for the daily operations. As long as things are done well, he does not interfere. I delegate further to the team leaders. They ensure that the work is done, and I do not interfere with how. (Departmental manager 2009)

Changes in the managers' perception of the employees' ability to contribute to the dayto-day development of the organization, and a change in the employees' assessment of their own competencies, were parallel processes:

Even if some of the employees are hesitant to take responsibility, the majority wants it. [...] What I see today is that people have changed. They see that they are as important as 
the top manager and myself. Today I do not have to correct them as much as I used to!

(Departmental manager 2009)

New work practices and routines. In accordance with the new management practices, the decision was made to establish SHWDP groups across departmental and hierarchical borders. These groups discussed how it would be possible to reduce work hours from 7.5 hours a shift to 6 hours, while keeping up with productivity and avoiding an increase in sickness absence rates. This resulted in considerable internal restructuring: shift schedules were changed, and work task assignments in the packaging department (assembly line work) changed from a line organizing toward a team-oriented structure. The employees now shifted positions along the assembly line and were expected to 'help out' and to be attentive to any problems or issues arising during work.

Transitioning from a community of colleagues toward practicing work teams. Because of this new structure, a sense of 'team spirit' emerged, and group-based learning developed. One employee described the change as follows:

We are more active now and come up with ideas. We were not supposed to do this before. Now we are more like a team. Everyone is happy to hear good ideas come up, regardless of who expresses them. (Employee 2009)

Another unanticipated result of SHWDP group work was that the group members experienced a change in their perception of themselves and of others:

I would never have guessed that we would have so many good ideas on how to do the work in a smarter way. (Employee 2009)

This way of thinking about oneself and others seeped into larger parts of the organization and contributed to the positive storytelling that became characteristic. The inclusion of the main union representative in the management group meetings was positively assessed. Openness, trust, and the opportunity to participate in and influence the ongoing change processes characterized the organization in this phase.

\section{Organizational defenses}

Despite all the above-mentioned positive development traits, three interrelated defensive routines emerged: (1) employees' resistance toward work in general and the SHWDPprocess specifically, (2) employees' cover-up strategies, and (3) managers' cover-up strategies. The interviews revealed that 'everybody knew' that someone was not participating in the process or doing their fair share of work. These colleagues were labeled 'the dodgers'. While lower-level managers kept this knowledge mostly to themselves - it was undiscussable (probably because they were assigned the responsibility to solve the problem) - some employees claimed to discuss it among themselves on occasion. Even though this was considered problematic because of the increased work and time pressure, it was not an issue for the open spaces. It took form of a cover-up of unpleasantness. The managers' strategy was to not address the issue in any way. The problem was expected to solve itself as the employees in question would 'probably come into the fold'. This did not happen (see phase III). 


\section{Phase III: Consolidation and standardization phase (2009-20 I 2)}

In the first part of this phase, the organization focused on maintenance and adjustments to the implemented SHWDP regime. By the end of this period, two potentially problematic issues surfaced: one was the level of participation in ongoing processes, and the other, interrelated, concerned low-level management's authority. The decision was made to 'relate further work to the principles of lean manufacturing'.

\section{Work environment}

In 2009, managers and employees agreed that the most important change in the work organization was that the employees themselves took responsibility for finding solutions to evolving problems. Even so, the changed break practice did not interfere negatively with the experienced mastery among the employees. We see this as a result of the learning that had taken place:

You avoid problems if you plan your work and prepare things for the next shift. Even if you do more in a shorter amount of time, you still feel that work is less hectic. I do not miss the joint breaks we used to have. Everything was messier then. Now, we focus on work and small individual breaks, if there is time. (Employee 2012)

There were some departmental differences. For example, the technical staff experienced more work task variation and a higher degree of control and autonomy. In this department, there were examples that some employees did work that exceeded their job description, such as adjusting a digital tool used to register product flow and facilitate new orders and production. The work pace was a more controllable factor in the storage department than in the packaging department. In the latter, work pace was dictated by the machines, and thus the feeling of being in control was less evident. Control over one's work relates to thinking ahead:

As soon as you press the start button, the work pace is fixed. But the clue is to be well prepared for what you know is coming up - the change of labels and so on. This saves time and helps keep productivity up. (Employee 2012)

The 2012 interviews reveal different employee adaption strategies. On the one hand, employees in all departments seem to have accepted the responsibility they had been given. These employees often had a flexible view of when the workday ended and on occasion prolonged it for as long as it took to see their assignment through. On the other hand, there were employees who only worked the specified hours and who could never imagine working extra time without pay. They argued according to time rationality, unlike those in the first group, who to a larger degree seem to have incorporated responsible autonomy. We cannot determine how common each of these strategies was, but we note that no one placed himself or herself in the 'clock-watching' category, but rather described certain colleagues that way.

In the technical department, we find productivity and cost awareness, tightly coupled with an understanding of one's own position in the organization. When the 
machines stop in the packaging department, it costs money, they said. This insight in turn led to a change in the way work tasks were organized and distributed and how stressful assignments were redistributed among the technical staff:

We have become better at doing projects together. In this way we can solve the problems quicker and get the machines to operative faster. (Employee 2012)

Because responsible autonomy takes place at a group level, it becomes possible to do these kinds of adjustments in the daily organizing of work tasks.

\section{Standardization, management, and organizational learning}

The 6-hour-workday and the rearrangement of shift schedules was a major positive contribution to job satisfaction and to a good work-life balance by the end of phase 2 . Three years later (2012), most employees took this for granted. By then, management issues and a 'leaner organizing' had come to the foreground, and reduced work hours has gone into the back. When asked direct questions on the issue, the awareness is raised again. There was consensus that 'if they take this away from us, production will drop and absenteeism will peak'. The 6-hour-workday partially works as a means of pressure, as a control mechanism, especially in periods with lower productivity. This relates to an agreement between the local management and the trade union, and between the local management and the central management of the dairy cooperative, stating that if productivity should fall or if sickness absenteeism should rise, then the agreement is broken and the project will be terminated.

In 2011, according to the top manager, it was decided to relate the further organizational development to some of the principles of 'lean organizing'. Other plants within the cooperative had already done this, and central management recommended it as a strategy. The following standardization tools were chosen: 5S, improvement group meetings, TPM, and A3. ${ }^{2}$ Overall equipment effectiveness (OEE) was also measured. Both managers and employees considered this a positive contribution to keep up performances:

It is important with regard to machine support, tidiness, and systems in general [...] because it provides documentation and visibility. We can be better at most things! (Union representative 2011)

It is an interesting paradox that tools guiding a 'leaner production' in this plant resulted in more employee participation. About a year after the implementation of new standardization tools, management expressed concern about the degree of involvement and participation. The meeting frequency and the number of participants had increased. In addition to the aforementioned 'improvement group meetings', new weekly 'blackboard meetings', where the previous week's production results were presented to the employees, took place. It was unclear whether discussions on the adequacy of involvement at this high level had been on the agenda in the weekly management meetings. According to the top manager (2011), the degree of involvement was becoming 'too time consuming', and he expressed a wish to use standardization tools to make it less extensive. To 
lower-level managers, the rising concern had to do with the performance of management roles. They considered exercising management and decision-making complicated within the 'involvement regime' in the organization:

You need to [...] let all suggestions surface, and then sometimes you need to participate in drawing the line. Finding the point of balance can be challenging. [...] The involved, cozy manager has become too dominating. (Line manager 2012)

Another rising managerial worry was the configuration of the improvement groups. In earlier phases of the development, the groups consisted of employees from various units. Now meetings took place within working units, for example, between assembly line colleagues. One departmental manager elaborated:

It takes more resources. [...] Perhaps you can improve the assembly line technically, but [...] we may have lost more than we gained. We don't get the whole picture anymore.

(Departmental manager 2011)

According to managers, at all levels, the execution of leadership had gradually become more and more a question of facilitation. The strong focus on participation at every level had paved the way for problem-seeking and finding solutions in a bottom-up fashion. The inclusion of assembly line workers in procurement processes (new machinery) was one example of a change in routines, but perhaps more important, also a change in the organizational attitude toward all organizational members. Changes to the machinery were made as the direct result of feedback from employees during a field trip to a manufacturer. The top manager further saw participation as a way of avoiding conflicts and potentially unsuccessful projects:

There is so much involvement that we seldom have conflicts. It is more the case that projects are stopped before they get started. The goal must be that most ideas come from those who perform the work tasks themselves. (Top manager 2012)

\section{Toward organizational learning}

In phase II, we described three parallel organizational defenses in action. In the first part of phase III, these defenses had not been dealt with. One explanation as to why management did not find a way to address this 'problem' is that the responsibility was delegated to the lower-level managers. These managers had been recruited from the operator level, and their notion of the strong sense of community among the workers may potentially have affected their perception of the available means for adjusting behavior. By the end of phase III, however, we see a significant change coming up:

Every assembly line is measured now and has [...] its own declared goals. We have a blackboard hanging out there to show 15-20 graphs. This has led to a certain competitiveness between lines and people. Those who work hard sort of correct the others - and they really have them going! In addition, this is also focused on in the improvement group 
meetings. We have seen a few examples of former dodgers who are now at the forefront!

(Departmental manager 2012)

We interpret this as an illustration of how organizational defenses, when addressed and reflected upon by organizational members who act on behalf of their organization, may result in productive organizational learning.

\section{Analysis and Discussion}

\section{Responsible autonomy and control}

In the first phase of the organizational development process, we see indications of a different set of system logics between managers and employees. The partially dysfunctional work organization (fear of reprisal, deep-rooted trust deficiency, etc.) comes together with a management practice based on control and supervision. A kind of workers' collective (Lysgaard, 1976) materialized, mainly focusing on 'getting through the day' with as little effort as possible, and leaving even the simplest problem-solving to low-level managers and technical staff. One aspect of the subscale of the control dimension - task authority (Karasek \& Theorell, 1990) - was nevertheless high at this stage. The ability to make decisions on how to perform work and to make job-related decisions was dominant. We see these factors, initially regarded positively by Karasek and Theorell, as elements of a nonproductive learning practice, even though they reinforced the social aspects of work. Putting work to rest whenever problems occurred boosted break practices and so added to the job satisfaction at the time. Even if there was a sense of logic to the (silent) joint decision not to solve solvable issues and not to discuss this practice openly (skilled incompetence), it acted as a defensive routine that prevented the organization from changing this practice and learning in a productive way (Argyris \& Schön, 1996). This finding is also in line with the sociotechnical concept of 'mutual scapegoating', which describes the community of employees as a self-perpetuating system where problems are considered unsolvable effects of the system, and thereby not a responsibility for either individuals or groups (Trist \& Bamforth, 1951).

So, even if a few aspects of employee control are high, we see that responsible autonomy is low (phase I). This can be explained by the lack of acceptance of responsibility for the totality of the work cycle, and the lack of ability (or willingness) to see oneself and others as interdependent parties (Trist et al., 1963). In this way, the combined perspectives of employee control, responsible autonomy, and defensive routines meet the critique of Karasek and Theorell's concept of control, namely, that the associational aspect of being in control was a missing link (Hvid, 2009; Karasek, 2008).

As the organizational development proceeded (phases II-III), several unanticipated benefits to the employees emerged. They experienced an increased sense of mastery, social support, and positive self-assessment, and work in itself became better organized and was viewed more positively. A significant change in the experience of control took place - the employees themselves considered skill discretion and task authority as high. The work pace, the content of work, and the cooperation between departments and between management and employees improved. The employees regarded themselves more as an interdependent part of a work team. By the end of phase III, the employees 
a) experienced job satisfaction through the discovery of new personal competencies, b) saw participation in the developmental processes as a way of acknowledgement and respect from the management, and c) as a way of getting closer to the decision-making processes. Whether these results are attributable to the increase in control and in responsible autonomy is debatable. The level of participation in the ongoing change processes can itself affect the perception of work. It is difficult to determine whether this participation per se can change the views of control and responsible autonomy. However, analyzing the development of the defensive routines in the organization in the same period, we see that there is a positive change by the end of phase III. At this stage, the degree of control and responsible autonomy is high, and the organization is finally on the verge of addressing (and probably solving) the issue of 'the dodgers'. We interpret this in support of the hypothesis that a high degree of responsible autonomy and employee control may affect the organizational ability to deal with organizational defenses that prohibit productive organizational learning.

\section{Responsible autonomy and productive organizational learning}

We see the organizational development in light of its historical and societal setting, as part of the Nordic work life tradition, influenced by the ideas of the sociotechnical school of thought (Enehaug, 2014). On the one hand, the case organization was - and is - experimenting with how to develop a model that increases participation, work task innovation, and organizational learning. On the other hand, the phase III-effort to standardize improvement efforts and production possibly represents a new way of looking at responsible autonomy, employee control, and learning.

Phase I was characterized not so much by organizational learning in itself as by making choices that in the longer run were important for the organizational learning capabilities. The changes in the top management, the MDP, and the inclusion of the union representative in management decision-making processes turned out to be the start of a positive development.

In phase II, we find examples of the first two forms of productive organizational learning. First, we see that the development of the new work organization that takes place in the SHWDP-process meets the criteria of type 1 - organizational inquires that lead to improved task performance. The new organization meets new demands by working in a more collaborative manner, increasing work pace, keeping machinery running, and so on. Second, we see that the change in mind-sets (development of new norms and values), and in structures and routines that took place in phase II is in line with type $2-$ organizational inquires in which the organization explores and restructures values and criteria for better performance. We suggest that the way employee control and responsible autonomy was developed as an integral part of the group-oriented development process also paved the way for productive organizational learning.

The standardization efforts that took place (by the use of certain 'lean tools') in phase III came about as a renewal of the established SHWDP. It was understood as a method to structure meetings, work tasks, and the training of employees (new and old), involve more employees than earlier, address issues in a more systematic fashion (e.g., problem solving and systems at work stations), and increase productivity further. By the end of the data collection period, these potential results seemed plausible. In effect, 
though, the new system also gave room for increased control of employees because of the possibility to break down production data to a lower level than earlier (shift/assembly lines/work teams). The presentation of these results (blackboard meetings, graphs) and the discussion of the results in improvement team meetings opened for new forms of peer surveillance. However, none of these factors was perceived as threatening or negative. We interpret this as a consequence of the already established work organization and employee work orientation (responsible autonomy). We find support in research that indicates that implementing lean in a context where internal relations are based on trust makes the necessary local adjustments easier (Rolfsen, 2014), and that organizations that have already developed learning-capacities may experience positive work environment effects (Edwards et al., 2010). Our finding is also in line with Røvik's (1997) argument that organizational members must translate general models into practice in order for them to be meaningful.

The standardization tools and the participatory and processual manner in which they were implemented, may also be considered a way of institutionalizing collective learning processes in an organization. Organizational learning, understood as a collective experience-based learning that focuses on how we work together and how we solve work tasks (Eikeland, 2006, 2012), may in fact be enhanced by the structuring of learning activities that takes place in the improvement groups, if the issues up for discussion are not limited in scope. We found no such restrictions. The new routines and structures that developed seemed to renew the commitment to the continuous improvement work in the organization - and to ensure continued focus on productivity measures.

\section{Responsibility - why and facing what?}

Through the three phases, the management gradually delegated the development of the new work organization to the employees through the SHWDP first and later in the 'improvement group meetings'. As opposed to phase I, the management control in phase II was more about result control than about supervision of work performance. The overall management style changed toward facilitative management, characterized by trust and confidence in employees' abilities to improve work performance. These changes included a shift toward responsible autonomy within the organization, which also contributed to the development of new control mechanisms. An increase in the social control- and in social support - emerged among employees. Control in itself is not a zero-sum game. The fact that there is an increase in responsible autonomy does not automatically imply less management control. New norms and values have developed at the same time as the employees' mindset has been in transition between the old and the new.

The 6-hour work day also acts as a control mechanism, especially in shorter intervals where productivity has fallen or the sickness absence rates have risen. Because nobody want to lose it, the focus on upholding the pace of work continues. Keeping the machines going with as few stoppages as possible, solving solvable issues without alerting team managers, being attentive beyond one's own work tasks, as well as being active participants in improvement groups may be seen as the internalization of the former management control. It may however also prove to be an example of internalized 
responsibility. The control mechanisms seem more integrated in the employees in phase III than in phase II. This can potentially give both positive and negative effects on the organizational learning capabilities. When the former contrasting systems logic of management and employees adjusts to each other, it is relevant to ask whether the necessary inquiries on behalf of the organization can still take place. What happens to critical thinking of the present when employees and management operate within the same kind of logic - when control is internalized full scale? Is it possible that the cooperative regime in this organization will prevent organizational learning of types 2 and 3? So far, we found no evidence to support this.

Responsible autonomy developed because of a critical change in the employees' social orientation. The overall condition of the SHWDP (sustain productivity) has changed the former Lysgaardian (1976) work orientation and has resulted in a merger between the (former dominant) technical system and the social system. A new system has emerged in which productivity improvement (the technical system) became embedded in the development of better quality jobs (a social systems factor).

\section{The key factors of success}

The overall concern of this article was to investigate the association between responsible autonomy, control, and productive organizational learning. We suggest that the SHWD-project manifested itself as a form of overarching solution to a stated problem within the organization, namely, the psychosocial and management problems described in the first phase of the organizational development (deep-rooted trust deficiency, fear of reprisal, 'skilled incompetence', mid-level managers' double bind, and escalation of top-down control mechanisms). The SHWDP came about as a kind of solution without initial form and content, as a learning challenge in itself (cf. Engeström, 2001). To find new ways of organizing the work in the process of setting up a 6-hour-workday became a task that large parts of the organization took part in. This employee-driven orientation can be seen as a consequence of several internal and external mechanisms. First, the ideas of IDPs were known and to a certain degree idealized by the new top manager (phase I). Second, the management group (phase II) regarded top-down guidelines as inadequate for this process - mostly because they were unsure how to reduce work hours and maintain (or improve) productivity and reduce sickness absence. We propose that responsible autonomy functioned as a design principle during the change process, through the focus on participation and development at every level of the organization, and in the top management's decision to delegate the design of the new work organization to the employees. Third, union representation in the management group became a way of gaining impact on the forthcoming development. Fourth, the management practice changed toward facilitation and focus on employee-driven innovation. Fifth, the employees saw participation in the process both as an asset in itself and as a prerequisite for a shorter and more convenient work schedule. The added value for the organization (increased productivity in phases II-III) was shared with the employees through the reduced work time (without wage income reduction). We see this an important factor for keeping up improvement efforts several years in a row. 


\section{Conclusion}

This article examined the association between responsible autonomy, employee control, and organizational learning in a longitudinal change process. The case study describes changes in industrial routine-based work. We expected that the development of responsible autonomy would be especially difficult to achieve in this setting. What we found, instead, was that the conditions for the development of autonomy lie in the development of organizational learning. In combination, these factors made it possible to adopt and adjust the few chosen lean tools that were implemented, and subsequently, prevent them from becoming destructive forces in the trust-based system that had been developed.

The critical case analysis indicates that the three theoretical concepts in question are interrelated and thus incomplete on their own terms. Autonomy is not only related to control and learning but also to responsibility. The challenge of successful organizational development lies in building responsibility through organizational learning. This case study describes the gradual implementation and development of responsible autonomy. We found that the productivity improvement and work environment changes that took place were possible through an employee-driven innovation process that led to an orientation toward quality, productivity, and learning throughout the organization. The analysis revealed that sharing productivity gains with the employees by implementing a 6-hour-workday contributed to the development of responsibility toward work task improvements, participation in change processes, and productive organizational learning. We also found that the development of responsible autonomy prevents defensive routines from disrupting processes of learning and development. We suggest that further research should seek to expand our understanding of employee responsibility as an embedded factor in the development of employee control, organizational learning, and responsible autonomy.

\section{References}

Argyris, C. (1990). Overcoming Organizational Defenses: Facilitating Organizational Learning, Boston: Allyn and Bacon.

Argyris, C. and Schön, D. A. (1996). Organizational Learning II: Theory, Method, and Practice, Reading, MA: Addison-Wesley.

Balzer, M., Westerlund, H., Backhans, M., et al. (2011). Involvement and structure: a qualitative study of organizational change and sickness absence among women in the public sector in Sweden, BMC Public Health 11: 1-17.

Bambra, C., Egan, M., Thomas, S., et al. (2007). The psychosocial and health effects of workplace reorganisation 2: a systematic review of task restructuring interventions, Journal of Epidemiology and Community Health 61: 1028-1037. doi: http://dx.doi.org/10.1136/ jech.2006.054999.

Clarke, A. (2005). Situational Analysis: Grounded Theory after the Postmodern Turn, Thousand Oaks, CA: Sage.

Creswell, J. W. (2013). Qualitative Inquiry \& Research Design: Choosing among Five Approaches, Los Angeles: Sage.

Dahl-Jørgensen, C. and Saksvik, P. Ø. (2005). An evaluation of the impact of two workplace interventions on the health of service workers. International Journal of Health Services 35: 529-549. 
DeWitte, H. (1999). Job insecurity and psychological well-being: review of the literature and exploration of some unresolved issues, European Journal of Work and Organizational Psychology 8: 155-177.

Dølvik, J. E. (2007). Konklusjoner: modernisering, konsolidering og nye utfordringer [Conclusions: modernization, consolidation, and new challenges]. In Dølvik, J.E, Fløtten, T., Hernes, G., et al. (eds) Hamskifte: Den norske modellen i endring [A new era: The Norwegian model in flux], Oslo: Gyldendal Akademisk, 283-316.

Edwards, K., Bojesen, A., Paarup Nielsen, A., et al. (2010). Lean og arbejdsmiljø - et dynamisk spandingsfelt [Lean and the work environment - a field of dynamic tension], Copenhagen: LR BUSINESS Egmont.

Egan, M., Bambra, C., Thomas, S., et al. (2007). The psychosocial and health effects of workplace reorganisation 1: a systematic review of organisational-level interventions that aim to increase employee control, Journal of Epidemiology and Community Health 61: 945-954. doi: http://dx.doi.org/10.1136/jech.2006.054965.

Eikeland, O. (2006). The validity of action research - validity in action research. In Aagaard Nielsen, K. and Svensson, L. (eds) Action and Interactive Research: Beyond Theory and Practice, Maastricht: Shaker, 193-240.

Eikeland O. (2012). Action research and organisational learning: a Norwegian approach to doing action research in complex organisations. Educational Action Research 20: 267-290.

Enehaug H. (2014). Læring i omstillingenes tid. Et teoretisk innspill om arbeidsmiljø og organisasjonslæring [Learning in the age of restructuring. A theoretical contribution to work environment and organizational learning]. Tidsskrift for Arbejdsliv 16: 69-84.

Enehaug H and Thune T. (2007). Organisasjonskultur og mennesker i fusjonsprosesser [Organizational culture and people in mergers and aquisitions], Oslo: Arbeidsforskningsinstituttet.

Engeström, Y. (2001). Expansive learning at work: toward an activity theoretical reconceptualization, Journal of Education and Work 14: 133-156. doi: http://dx.doi. org/10.1080/13639080020028747.

Falkum, E., Ingelsrud, M. H. and Nordrik, B. (2016) Medbestemmelsesbarometeret 2016 [The codetermination barometer 2016] Oslo: Arbeidsforskningsinstituttet/HiOA.

Falkum, E. (2015). Institutionalization and dynamic change of institutions: the Basic Agreement and tripartite structures in Norway. In Engelstad, F. and Hagelund, A. (eds) Cooperation and Conflict the Nordic Way: Work, Welfare, and Institutional Change in Scandinavia, Berlin: De Gruyter Open, 56-76.

Gardell B and Svensson L. (1981). Medbestämmande och självstyre - en lokal facklig strategi för demokratisering av arbetsplatsen [Co-determination and autonomy - a local union strategy for democratization of the workplace], Stockholm: Prisma.

Gustavsen, B. (2007). Work organization and 'the Scandinavian model', Economic and Industrial Democracy 28: 650-671. doi: http://dx.doi.org/10.1177/0143831X07082218.

Gustavsen, B., Qvale, T. U., Sørensen, B. A., et al. (2010). Innovasjonssamarbeid mellom bedrifter og forskning - den norske modellen [Innovation partnership between businesses and research - the Norwegian model], Oslo: Gyldendal Akademisk.

Gustavsen, B. (2011). The Nordic model of work organization, Journal of Knowledge Economy 2 (4): 463-480. doi: http://dx.doi.org/10.1007/s13132-011-0064-5.

Hasle P and Sørensen OH. (2013). Employees as Individually and Collectively Acting Subjects- Key Contributions from Nordic Working Life Research. Nordic Journal of working life studies 3: 9-28. doi: http://dx.doi.org/10.19154/njwls.v3i3.3009.

Heiret, J. (2012). Three Norwegian varieties of a Norwegian model, Nordic Journal of Working Life Studies 2: 45-66.

Herbst, P. G. (1971). Demokratiseringsprosessen i arbeidslivet: Sosio-tekniske studier [The work life democracy process: Sociotechnical studies], Oslo: Universitetsforlaget. 
Holter, Ø. G., Karlsen, B., Salomon, R., et al. (1998). Omstillinger i arbeidslivet [Work life Restructuring], Oslo: Arbeidsforskningsinstituttet.

Hvid, H. S. (2009). To be in control: vejen til godt psykisk arbejdsmiljø, læring og innovation [To be in control: the road toward a sound psychological work environment, learning, and innovation], Tidsskrift for Arbejdsliv: 11-30.

Hvid, H. (2013). Arbejdspladsbaseret innovation \& produktivitet: nordiske erfaringer [Workplace-based innovation and productivity: Nordic experiences; Skriftserie for CAF 2013:2], Roskilde: Roskilde Universitet, 1-22.

Jacobs, G., van Witteloostuijn, A. and Christe-Zeyse, J. (2013). A theoretical framework of organizational change, Journal of Organizational Change Management 26: 772-792. doi: http://dx.doi.org/10.1108/JOCM-09-2012-0137.

Karasek, R. (1979). Job demands, job decision latitude, and mental strain: implications for job redesign, Administrative Science Quarterly 24: 285-308. doi: http://dx.doi. org/10.2307/2392498.

Karasek, R. (2008). Low social control and physiological de-regulation: the stress-disequilibrium theory, towards a new demand/control model, Scandinavian Journal of Work Environment and Health: 117-135.

Karasek, R. and Theorell, T. (1990). Healthy Work: Stress, Productivity, and the Reconstruction of Working Life, [New York]: Basic Books.

Kasvio, A., Gonäs, I. J. and Skorstad, E. (2012). In search of the Nordic working life model: introduction to the thematic issue, Nordic Journal of Working Life Studies 2: 1-19. doi: http://dx.doi.org/10.19154/njwls.v2i4.2302.

Kivimäki, M., Vahtera, J., Elovainio, M., et al. (2003). Human costs of organizational downsizing: comparing health trends between leavers and stayers, American Journal of Community Psychology 32: 57-67.

Korunka, C., Scharitzer, D., Carayon, P., et al. (2003). Employee strain and job satisfaction related to an implementation of quality in a public service organization: a longitudinal study, Work \& Stress 17: 52-72. doi: http://dx.doi.org/10.1080/0267837031000109526.

Lysgaard, S. (1976). Arbeiderkollektivet: En studie i de underordnedes sosiologi [The workers' collective: A study of the subordinates' sociology], Stavanger: Universitetsforlaget.

Nytrø, K., Saksvik, P. Ø., Mikkelsen, A., et al. (2000). An appraisal of key factors in the implementation of occupational stress interventions, Work \& Stress 14: 213-225. doi: http:// dx.doi.org/10.1080/02678370010024749.

Patton MQ. (2002). Qualitative research \& evaluation methods. Third Edition, Thousand Oaks, CA: Sage Publications.

Rolfsen, M. (ed) (2014). Lean blir norsk: Lean i den norske samarbeidsmodellen [Lean becomes Norwegian: Lean in the Norwegian cooperative model], Bergen: Fagbokforlaget.

Røvik, K. A. (1997). Trender og translasjoner: Ideer som former det 21. arhundrets organisasjoner [Trends and translations: Ideas that are forming 21st-century organizations], Oslo: Universitetsforlaget.

Røvik, K. A. (1998). Moderne organisasjoner: trender $i$ organisasjonstenkningen ved tusenairsskiftet [Modern organizations: trends in organizational theory at the dawn of a new millennium], Bergen-Sandviken: Fagbokforlaget.

Saksvik, P. Ø., Nytrø K., Dahl-Jørgensen C., et al. (2002). A process evaluation of individual and organizational occupational stress and health interventions, Work \& Stress 16: 37-57. doi: http://dx.doi.org/10.1080/02678370110118744.

Sørensen OH, Hasle P, Hesselholt RR, et al. (2012). Nordiske forskningsperspektiver på arbejdsmiljø. Mening, indflydelse og samarbejde [Nordic Research perspectives on work environment. Meaning, influence and cooperation]. In: Norden (ed) TemaNord. København: Nordisk Ministerråd. 
Thorsrud, E. and Emery, F. E. (1970). Mot en ny bedriftsorganisasjon: Eksperimenter i industrielt demokrati. Fra Samarbeidsprosjektet LO/NAF [Toward a new company organization: Experiments in industrial democracy], Oslo: Johan Grundt Tanum Forlag.

Trist E., and Bamforth K. (1951). The stress of isolated dependence: the filling shift in the semi-mechanized longwall three-shift mining cycle. A shortened version of: Some social and psychological consequences of the longwall method of coal-getting], Human Relations 4: 3-38

Trist E., Higgin G. W., Murray H. and Pollock, A. B (1963). Organizational Choice: Capabilities of Groups at the Coal Face under Changing Technologies. The Loss, Re-discovery of Transformation of a Work Tradition, London: Tavistock Publications.

Weick, K. E. and Quinn, R. E. (1999). Organizational change and development, Annual Review of Psychology 50: 361-386. doi: http://dx.doi.org/10.1146/annurev.psych.50.1.361.

Yin, R. K. (2014). Case Study Research: Design and Methods, 5th edition, Los Angeles: Sage.

\section{End notes}

${ }^{1}$ All employees were invited to participate in the 2009 survey, but technical problems contributed to a low response rate $(56 \%)$. Thirty-three percent of the respondents were women and $67 \%$ were men. This gender distribution is close to the company gender distribution $(38 / 62)$.

2 5S: The principle of waste elimination through workplace organization. Total Productive Maintenance: A system for predicting the maintenance needs of equipment so that machine breakdowns are minimized. This methodology uses statistics and standardized work processes within the maintenance function. Another component of this technique is that machine operators are trained in many of the day-to-day maintenance tasks. A3: A one-page reporting format featuring critical information about an issue, such as description, cost, timing, data, planned solution, and planned resolution (http://www.axiom-adal. com/page77.html). 